\title{
Planting of Cut Potato Tubers in India and Global: Urgent Need of Planter Mechanization to Produce Higher Tuber Yield
}

ISSN: 2637-8078

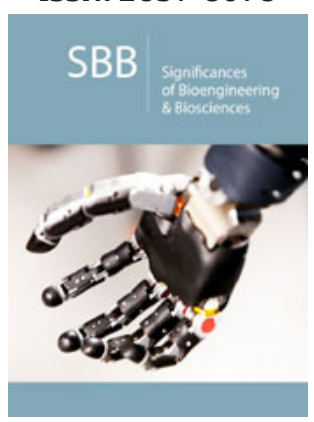

*Corresponding author: Chethan CR, ICAR-Directorate of Weed Research, Jabalpur-482004, India

Submission: 眥 January 6, 2021

Published: 㑘January 20, 2021

Volume 4 - Issue 3

How to cite this article: Chethan $\mathrm{CR}$ Tewari VK, Shrivastava AK, Nare B, Kumar SP. Planting of Cut Potato Tubers in India and Global: Urgent Need of Planter Mechanization to Produce Higher Tuber Yield. 4(3). SBB. 000589. 2021. DOI: 10.31031/SBB.2021.04.000589

Copyright@ Chethan CR, This article is distributed under the terms of the Creative Commons Attribution 4.0 International License, which permits unrestricted use and redistribution provided that the original author and source are credited.

\author{
Chethan $\mathrm{CR}^{1 *}$, Tewari $\mathrm{VK}^{2}$, Shrivastava $\mathrm{AK}^{3 *}$, Nare $\mathrm{B}^{4}$ and Kumar $\mathrm{SP}^{5}$ \\ ${ }^{1}$ ICAR-Directorate of Weed Research, Jabalpur, India \\ ${ }^{2}$ Indian Institute of Technology, Kharagpur, India \\ ${ }^{3} J a w a h a r l a l ~ N e h r u$, Krishi Vishwa Vidyalaya, Jabalpur, India \\ ${ }^{4}$ ICAR-Central Potato Research Station, Jalandhar, India \\ ${ }^{5}$ ICAR-Central Institute of Agricultural Engineering, Bhopal, India
}

\section{Abstract}

Potato is a major food crop of the world and mostly grown as edible crop. It stands fourth position in cultivation at global level after rice, wheat and maize crops. Potatoes are traditionally grown by whole tubers; however, they can also be grown by other vegetative organs. During potato planting season it has predicated and seen an acute shortage of seed tubers. The cost of seed tuber alone accounts about 36$38 \%$ percent of total cost of cultivation of potato. Planting of cut tubers is increasing in Asia and other parts of the world day by day to reduce seed cost. Presently, cut tubers were planted through existing planters without considering a tuber sprout eye orientations. This causes tuber decay, germination loss and reduced tuber yield. Development of new and novel planters can overcome the above said problems and will increase the tuber yield. To achieve this objective, a novel potato planter was developed at ICARDirectorate of Weed Research, Jabalpur, which plants the cut tubers by orienting their sprout-eyes in right direction. The planter also increased the tuber yield by 14.5-20\% over existing planter.

Keywords: Cut tubers; Planter; Potato; Seed tubers; Sprout eye

\section{Mini Review}

Potato (Solanum tuberosum L.) family (Solanaceae) is one of the most important food crop and abundantly grown edible crop in the world. Potato is native to the South America, but cultivated all over the world and stands fourth position in cultivation after rice, wheat and maize [1]. Likewise, in India also, the potato ranks fourth most important food crop after rice, wheat and maize and accounts 1.23 percent of gross agricultural production. India is the second largest producer of potato after China with a production of 51.3 million tonnes from 2.14 million hectare area, having an average productivity of $23.96 \mathrm{Mt} /$ ha during 2017 18. During 2016, India produced a 44 million tonnes of potato out of 377 million tonnes of world production, which holds a share of about $11.6 \%$ of global production [2]. The potatoes are largely grown in the cooler regions, where mean temperature of the location does not exceed $18{ }^{\circ} \mathrm{C}$ during growing season. In India potato is grown in almost all the states, however the Indo-Gangetic plains comprising Uttar Pradesh, West Bengal, Bihar, Punjab and Haryana states shares 80 percent of production from national total production [3]. The state wise production status of Indian states is given in (Figure 1). A clear comparison of the production and productivity of potato within Indian states is briefed in (Table 1). Potatoes are traditionally grown by the whole tubers, but it can also be grown by other vegetative organs such as sprouts and true seeds. Potato plant has a multiplication rate ranging from 1:10 to 1:15. The tuber has buds, also called "eyes", arranged in a spiral manner, from which sprouts and shoots develop. Tubers of 40-60g are commonly used as seed potatoes, larger tubers are cut into two to four pieces containing at least one eye. The seed is a costly and critical input in potato production and it alone accounts about 36-38\% percent of the total cost of cultivation $[4,5]$ in potato production. The situation of increase in seed cost further increases 
and becomes prime most factors in the cultivars, which produces the large size tubers. There is an acute shortage of small size (10$20 \mathrm{~g}$ ) healthy seed tubers during planting season of the potatoes. It has been predicted ad observed that, there will be a short fall of available certified and quality gram, lentil, pea, soybean and potato seeds in India [6]. It is necessitated to take necessary steps to avoid the shortages of certified seeds. The possible solution for this problem is that the large tubers may be cut into two or more seed pieces and cut seed piece should have at least one sprout eye on them.

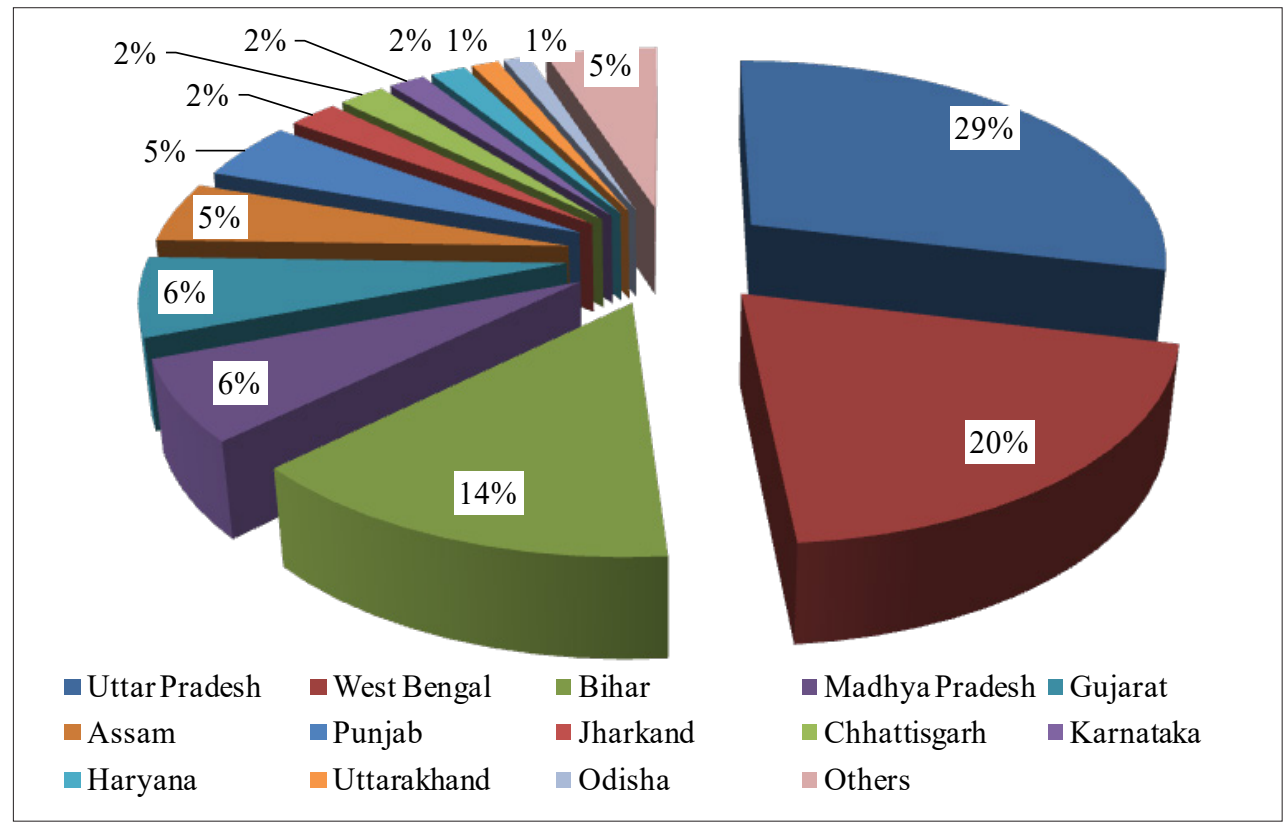

Figure 1: Percentage share of potato cultivated area during 2017-18, state wise in India.

Table 1: State wise area of crop cultivation, production and productivity of potato in India during 2017-18. Source: Anon, 2018.

\begin{tabular}{|c|c|c|c|c|}
\hline S. No. & State & Area ('000 ha) & Production ('000 Mt) & Productivity (Mt/ha) \\
\hline 1 & Andhra Pradesh & 3.93 & 68.29 & 17.36 \\
\hline 2 & Assam & 102.87 & 720.97 & 7.01 \\
\hline 3 & Bihar & 304.78 & 7740.79 & 25.4 \\
\hline 4 & Chhattisgarh & 44.87 & 694.61 & 15.48 \\
\hline 5 & Gujarat & 133.29 & 3806.95 & 28.56 \\
\hline 6 & Haryana & 34.72 & 897.58 & 25.85 \\
\hline 7 & Himachal Pradesh & 15.88 & 198.66 & 12.51 \\
\hline 8 & Jammu \& Kashmir & 5.17 & 110.24 & 21.32 \\
\hline 9 & Jharkhand & 48.21 & 690.23 & 14.32 \\
\hline 10 & Karnataka & 35.53 & 509.48 & 14.34 \\
\hline 11 & Kerala & 0.5 & 7.5 & 15.01 \\
\hline 12 & Madhya Pradesh & 136.29 & 3144.64 & 23.07 \\
\hline 13 & Maharashtra & 11.09 & 259.22 & 23.38 \\
\hline 14 & Meghalaya & 18.92 & 187.95 & 9.93 \\
\hline 15 & Mizoram & 0.09 & 0.93 & 10.33 \\
\hline 16 & Nagaland & 4.92 & 65.02 & 13.23 \\
\hline 17 & Odisha & 25.09 & 298.06 & 11.88 \\
\hline 18 & Punjab & 98.52 & 2571.04 & 26.1 \\
\hline 19 & Rajasthan & 13.82 & 278.52 & 20.15 \\
\hline
\end{tabular}




\begin{tabular}{|c|c|c|c|c|}
\hline 20 & Sikkim & 19.14 & 89.91 & 4.7 \\
\hline 21 & Tamil Nadu & 3.51 & 67.66 & 19.3 \\
\hline 22 & Telangana & 3.35 & 42.44 & 12.66 \\
\hline 23 & Tripura & 7.99 & 144.53 & 25.3 \\
\hline 24 & Uttar Pradesh & 614.78 & 362.16 & 13.76 \\
\hline 25 & Uttarakhand & 26.3 & 12782.5 & 29.9 \\
\hline 26 & West Bengal & 427.5 & 14.61 & 21.84 \\
\hline 27 & Others & 0.67 & 51310.02 & Average $=23.96$ \\
\hline
\end{tabular}

Table 1 reveals that, the West Bengal state had higher productivity of 29.9t/ha and Uttar Pradesh highest cultivated area of $6.15 \times 10^{5}$ hectares. The demand for growing of potatoes from cut tubers is increasing in Asia day by day, because the availability of disease free tubers is a biggest problem and often, they are costlier during sowing period. In Southeast Asia and developing countries most of the farmers prefers small seed piece with at least one eye, as it reduces seed requirement by about 50 percent, covers large area as much as possible with the minimum input of seed, and consequently declines total cost of cultivation by 25 percent $[7,8]$. The tubers cut into equal half pieces longitudinally and used as the seeds, these seeds may contain at least one sprouteye portion, which will help in germination. The proper orientation of the sprout-eye of the tubers during planting is most important, as the eye orientation affects the tuber germination, plant vigour and tuber production. A special care should be taken to maintain the sprout-eye oriented upward direction to avoid seed decay and healthy growth of plant. The researchers such as Escobar and Zaag [9], Adhikari [7] and others showed that, the yield performance from the cut tubers were comparatively higher than the whole tubers and true potato seeds in warmer regions. At present, very less work has been done to develop planters for cut seed pieces of the potato tubers and they are planted by existing potato planters. These planters were developed specially to plant whole tubers and it involves the mechanism of random dropping of tubers into the furrow without considering sprout eye orientation of tubers. Planting of cut seed pieces of potato tubers by the planters developed for whole tubers, causes damage to the tuber sprouts and orient the sprout eyes towards downward direction during most of the times. This increases mean germination time of tuber, decays plated tubers and decreases the plant emergence, hampers the plant growth and vigour and finally drastically reduces the tuber yield [10]. Therefore, a novel special planter which orients the sprout eyes of tubers in upward direction, needs to be developed.

\section{Conclusion}

To achieve this objective so many researchers have tried to develop different planters. One such novel planter was developed at
ICAR-Directorate of Weed Research, Jabalpur, India in collaboration with Indian Institute of Technology, Kharagpur, India. The developed planter orients the sprout-eyes of cut potato tubers in right direction and plants it in the furrow. Planting of cut tubers by this developed planter improves the tuber yield by 14.5 to $20 \%$ over existing planter. Thus, modification and improvement aspect in the existing planter needs to look into more mechanization needs to be achieved in planting of cut tubers.

\section{References}

1. Khurana SM Paul (2002) Research and development support by CPRI for potato export, storage and processing. J of Indian Potato Association 29: 67-75.

2. (2018) Horticultural statistics at a glance 2018. Horticulture Statistics Division, Department of Agriculture, Cooperation \& Farmers' Welfare, Ministry of Agriculture \& Farmers' Welfare, Government of India, India. pp. 1-490.

3. (2006) Package of organic practices from Uttaranchal for chilli, mustard, potato and soybean. The Institute of Himalayan Environmental Research and Education, India. pp. 1-102.

4. Peer QJA, Ahmad N, Kaur J, Chesti MH, Ahmad HS, et al. (2013) Study on economics of potato growing towards livelihood security. African J of Agric Res 8(45): 5639-5644.

5. Raghuvanshi A, Gauraha AK, Chandrakar MR (2018) Trends and economics of cultivation of potato in Chhattisgarh. J of Pharmacognosy and Phytochemistry 7(3): 3150-3153.

6. Subramanian A (2015) Economic survey 2014-15. Ministry of Finance, Government of India, India.

7. Adhikari RC (2005) Performance of different size true potato seed seedling tubers at Khumaltar. Nepal Agric Res J 6: 28-34.

8. Arsenault WJ, LeBlanc DA, Tai GCC, Boswall P (2001) Effects of nitrogen application and seed piece spacing on yield and tuber size distribution in eight potato cultivars. American J of Potato Res 78: 301-309.

9. Escobar G, Zaag PV, Vanderzaag P (1988) Field performance of potato (Solanum spp.) cuttings in the warm tropics; imfluence of planting system, hilling, den- sity and pruning. American Potato J 65: 1-10.

10. Chethan CR, Tewari VK, Srivastava AK, Kumar SP, Nare B, et al. (2019) Effect of herbicides on weed control and potato tuber yield under different tuber eye orientations. Indian J of Weed Sci 51(4): 385-389. 